\title{
Philosophy and the Integrity of the Person: The Phenomenology of Robert Sokolowski
}

\author{
Molly Brigid McGrath
}

\begin{abstract}
This chapter offers an overview of the philosophy of Robert S. Sokolowski with a focus on his account of what philosophy is, how philosophy arises out of prephilosophical life, and how it is related back to pre-philosophical life. It also situates Sokolowsk's achievements in articulating the relationship between Husserlian phenomenology and modern and pre-modern styles of philosophizing.
\end{abstract}

Keywords Robert Sokolowski · Edmund Husserl · Phenomenology · Truth · Philosophy $\cdot$ Personhood

\begin{abstract}
It dawned on me rather abruptly ... that when we think we directly articulate the world and the things in it, that we do not rearrange and combine sense data or ideas or concepts. Things and the world are present to us and we articulate their presences. There we are, the world and us, with nothing in between. This, the fact that thinking is outside and public from the start, was the point of Husserl's teaching on intentionality.... This direct involvement of ourselves in the world was also the point of Husserl's transcendental reduction. The purpose of the reduction is not to encapsulate ourselves in ourselves, but to come to see ourselves and the world in correlation. We in our reason are the articulators of the world, and the world presents itself to our articulation, and philosophy is the contemplation of how this happens, the description of "the world in its human involvement", to use one of [Francis] Slade's expressions.

Robert Sokolowski, "Husserl as Tutor in Philosophy"1
\end{abstract}

Robert S. Sokolowski began as an interpreter of Husserl to North American audiences and justly gained the reputation for his care and clarity in this role. After sketching Sokolowski's career, development, and major works, this essay recapitulates one of his most important contributions to phenomenology. Namely, he articulates, in a way appropriate to our historical situation, what philosophy is and how phenomenological philosophy allows us, in our place and time, to recover in a new way the perennial activity of philosophizing. ${ }^{1}$ Sokolowski, Robert. 1988. "Husserl as Tutor in Philosophy". Journal of the British Society for
Phenomenology 19, no. 3:296.

M. B. McGrath ( $\triangle)$

Assumption College, Worcester, MA, USA

(C) Springer Nature Switzerland AG 2019

187

M. B. Ferri (ed.), The Reception of Husserlian Phenomenology in North America,

Contributions To Phenomenology 100,

https://doi.org/10.1007/978-3-319-99185-6_11

mollybflynn@gmail.com 
Sokolowski (1934-) is currently Elizabeth Breckenridge Caldwell Professor of Philosophy at The Catholic University of America. He completed his Ph.D. at The Catholic University of Louvain in 1963 after earning a B.A. and M.A. in philosophy at The Catholic University of America and an S.T.B in theology at The Catholic University of Louvain. He began teaching at The Catholic University of America in 1963 and has also served in a visiting capacity at The New School for Social Research (1969-1970), The University of Texas at Austin (1978), Villanova University (1983), and Yale University (1992). Originally from New Britain, Connecticut, he is a Roman Catholic priest in the Archdiocese of Hartford and was named monsignor in 1993. He served as an auxiliary chaplain at Bolling Air Force Base in Washington, D.C., for nearly 20 years (1976-1995). For eight (1981-1989) he served as a consultant at Los Alamos National Laboratory, where he gave the J. Robert Oppenheimer Lecture in 1996.

Before a sketch of Sokolowski's scholarly contributions, it is worth remarking on his teaching, given that the breadth of his influence on North American philosophy has come not only through his publications, but also through the significant number of students who have been fortunate enough to encounter him in the classroom. Because he has taught mostly graduate students in philosophy and also in theology, many have become professors or priests who have then gone on to influence others. $\mathrm{He}$ is known in the classroom for a clarity and carefulness with details. His deep voice, his dry and smart sense of humor, and his pictures on the board displaying fine distinctions in intentionality mark his pedagogy at a surface level, but also, more deeply, he is attentive to the way in which people come to learn. He takes teaching seriously as a service to his students and to the common good. His classroom presence and presentation of material - the way he leads his students in thought—evidence his patience, gentility, and generosity. For example, in his courses, he provides students with his chapter-by-chapter notes and commentary on the classic texts he is teaching, notes which are often collected by and shared among his students.

As a specialist in Husserlian phenomenology, he has frequently taught courses focused on Husserl's Transcendental and Formal Logic (which, he has commented, is Husserl's best work and too often overlooked), Cartesian Meditations, and The Crisis of European Sciences and Transcendental Phenomenology. Other regular courses of his include ones focused on Aristotle's Politics and on Hobbes' Leviathan (two books he has said are especially illuminating when juxtaposed), Aristotle's Metaphysics, Virtue and Human Action, and Functions of Philosophy in Theology. Teaching is partly done through the content of one's articulations, but it is done also by example, by the attitude one displays toward one's topics. Gratefully, one often discovers in Sokolowski's students virtues he displayed to them in the classroom, for example, a calm toward large questions, an attentiveness to the categorialities that structure our lives, a skill at minding and reminding others of important distinctions, and an appreciation for the marvelous way that human reason apprehends reality, however imperfectly.

His phenomenology covers a broad array of topics: syntax, predication, and categorial form; natural law; the nature of the professions; human character and the 
virtues; artificial intelligence; philosophy of mathematics (with Gian-Carlo Rota); metaphysics; the categoriality of human practical life; philosophy of language; judgments, propositions, and philosophy of logic; time; political philosophy; the human soul and spirit; the visual arts; and Aristotle's metaphysics, ethics, and logic. He has authored eleven books in phenomenology, more than one hundred scholarly articles, and many insightful book reviews on wide-ranging topics and thinkers from the history of philosophy. Several conferences, a lecture series, and two edited volumes have been dedicated to examining his work. ${ }^{2}$

\section{Overview of Sokolowski's Major Works}

Robert Sokolowski's first two books, The Formation of Husserl's Concept of Constitution (1964) and Husserlian Meditations: How Words Present Things (1974), illustrate why he has been so valuable to English-speaking audiences seeking to understand Husserlian phenomenology, but the change from the first to the second also indicates the trajectory he was subsequently to take. While The Formation of Husserl's Concept of Constitution is a scrupulous step-wise tracing of what its title names, Husserlian Meditations shows Sokolowski's own philosophical genius more clearly. In Husserlian Meditations, Sokolowski repackages Husserl dynamicallydeveloping especially three themes of Husserl's, parts and whole, identity in manifolds, and empty and filled intentions-allowing readers to appreciate the significance of the philosophical basics of Husserl's work in a way that may be lost when navigating either Husserl's own writings or Sokolowski's workmanlike treatment of Husserl's development in The Formation.

Husserlian Meditations concludes with a discussion of philosophy's service to prephilosophical life as "warding off confusion and sophistry" and with an articulation of one of philosophy's own particular joys: "philosophy as phenomenology enjoys the disclosure of things. It delights in all things that are delightful, but enjoys them specifically in their being manifest. It further appreciates the human process of being truthful, which allows things to be recognized for what they are". ${ }^{3}$ One of Sokolowski's influences on readers and students has been this ethic of philosophy in its phenomenological mode: it is one particularly wonderful way in which human beings exercise their truthfulness, a way in which we admire the display of beings and respect human persons in their apprehensions of the world.

A significant jump occurs in the development of Sokolowski's phenomenology in his third book, Presence and Absence: A Philosophical Investigation of Being

\footnotetext{
${ }^{2}$ The two edited volumes are The Truthful and the Good: Essays in Honor of Robert Sokolowski, edited by John J. Drummond and James G. Hart (Boston: Kluwer Academic Publishers, 1996), and Ethics and Theological Disclosures: The Thought of Robert Sokolowski, edited by Guy Mansini and James G. Hart (Washington: The Catholic University of America Press, 2003).

${ }^{3}$ Sokolowski, Robert. 1974. Husserlian Meditations: How Words Present Things. Evanston: Northwestern University Press, 270.
} 
and Language (1978). In a run, when one is just getting started, the first mile or two give way (for the author, in the third mile) to a feeling of being at home with oneself in the free, easily coordinated movement of limbs and lungs, bringing with it clearness of mind as a gift. One gets the sense, in reading his first few books, that Sokolowski's third book is his third mile. In Presence and Absence, he seems to move more as himself. If seeking to understand Husserl with Sokolowski's guidance, Husserlian Meditations is the more helpful book. If seeking to understand what else we can do with Husserl's accomplishments, Presence and Absence might be preferred.

Presence and Absence begins as an exploration of the basic elements of language, the name and the verb, and articulates how language opens us up to the world. When doing phenomenological analyses, Sokolowski dependably draws out their broader human significance. For example, in the process of learning to name, the child recognizes that the object remains what it is when out of touch and sight, that it transcends both its presence and its absence. This is not merely a cognitive achievement, but also an emotional development: "The importance of consistent delay and gratification for a child lies in getting him used to mastering succession, to tolerating separation without panic, and in engendering confidence that what he desires will come back". ${ }^{4}$ This is a maturation of the person's emotions and a growth of the person's sense of self, for "The sufferer must come to realize that he is not identified with his affliction and that he will be released from it" this is true not of children only. This is done in a special way through the power of naming, for when a person makes "a desirable or distressing thing" nameable, "its affective spell is broken". ${ }^{6}$ The absence of worldly things, an absence that reality's objectivity affords and that is made possible for us by language, protects both the world's integrity and our own. A parallel process occurs as the person develops the ability to distinguish facts and propositions, to suspend the truth of a claim while still considering it: "The emergence of the proposition allows us to take a distance to our own convictions". ${ }^{7}$ The fuller importance that Sokolowski articulates of this development of the proposition will be discussed further below.

In Presence and Absence, Sokolowski also elaborates upon Husserl's claim in the Logical Investigations that words are indication signs of thought. "Words, and the sentence as a whole, can be understood as signals". ${ }^{9}$ Namely, "they signal that the speaker achieves the syntax, if he speaks thoughtfully, and they simultaneously signal to the hearer to perform the propositional move himself. The one grammatical achievement signals in both directions". ${ }^{10}$ When the person becomes aware of

\footnotetext{
${ }^{4}$ Sokolowski, Robert. 1978. Presence and Absence: A Philosophical Investigation of Language and Being. Bloomington: Indiana University Press, 26.

${ }^{5}$ Ibid.

${ }^{6}$ Ibid., 27.

${ }^{7}$ Ibid., 61.

${ }^{8}$ Ibid., 115.

${ }^{9}$ Ibid., 100.

${ }^{10}$ Ibid., 122.
} 
words as signaling in these ways, he can then be more attentive to what he intimates to others (in a way that opens up the possibility of rhetoric, for example) and can be more awake to others as responsible for their claims: "The loss of naivety in a critical listener is his becoming aware of the signal as signal, and this is the inhibition of assent which we have called the propositional turn". ${ }^{11}$

Following Presence and Absence, Sokolowski embarked upon more phenomenological work that, while obviously indebted to Husserl, illustrates Sokolowski's original phenomenological style. Marking the difference from The Formation (1964), on the one hand, to Moral Action: A Phenomenological Study (1985) and Pictures, Quotations, and Distinctions (1992), on the other, we see that Sokolowski has moved from explaining Husserlian phenomenology to appropriating it for his own philosophical purposes.

Moral Action is dedicated to describing practical intentionality and especially the "categorialities that make up phronêsis", prudence or practical wisdom. ${ }^{12}$ It begins by developing the distinction between the voluntary and the chosen, phenomenologically recapitulating and elaborating upon Aristotle's treatment of the structure of human action in Nicomachean Ethics III. Sokolowski emphasizes that moral action is, by way of a categorial form, identified with and founded on more basic actions, which serve as their material substrates. Here he employs Husserl's discovery of intentionality and of categorial objects, which he explains is a discovery that may seem small. Its importance is hard to see, he says: "because it is a beginning, it occurs in a setting in which everything else remains the same as it was before the discovery was made". ${ }^{13} \mathrm{He}$ also adapts Heidegger's ontological difference, our awareness of a being and its showing up, into a moral ontological difference: while the good appears to us, so does its seeming as good, and this phenomenological gap provides the space in which moral action arises. Putting these together with Aristotle's discussions of the structure of human action, of friendship, and of the relation between matter and form, Sokolowski describes how in moral action we publically inform a substrate action-e.g., giving a gift, striking someone-with a complex interpersonal form by acting in the light of our recognition of the action as good for me in being good or bad for the other person. The analysis defends the integrity of human action as publically and intrinsically meaningful, as reducible neither to some internal intention or act of will nor to its results or consequences.

Phenomenology of the Human Person (2008) is in some respects a reworking and elaboration of themes developed in Presence and Absence. Here Sokolowski synthesizes many issues from metaphysics, philosophy of language, and philosophical anthropology, engaging contemporary linguistics, psychology, literature, and philosophy as well as classic texts from all eras of the history of philosophy. His goal is a description of the human person that reveals for us how the person is essentially

\footnotetext{
${ }^{11}$ Ibid., 102.

${ }^{12}$ Ibid., 5.

${ }^{13}$ Ibid., 1.
} 
marked in all his human activities by veracity, an erotic rationality directed toward truth (even our irrationalities evidence our rationality, as all perversions can be understood only as distortions of well-ordered desire). Recapitulating the classical tradition and extending our understanding of rationality, Sokolowski shows how reason suffuses our shared human life, from mundane conversations about, e.g., sick trees to practical and moral action to the attempt to understand the whole and our place in it. In doing so, Sokolowski defends the integrity and responsibility of the person as agent and dative of truth and defends the integrity and givenness of reality as affording, and worthy of, our rational engagement.

This - veracity and the integrity of the human person - is the unifying theme of his oeuvre. In Husserlian phenomenology, he comments, "the human being, as thinker and agent, is also validated in its own integrity, with the absences and vaguenesses and ambiguities that are proper to it". ${ }^{14}$ And this defense of the person is, correlatively, a defense of the reality to which the person is related: "The validity of things and the truth of human being are mutually related. One cannot philosophically acknowledge our human being unless one also acknowledges the things that we are involved with". ${ }^{15}$

One important theme of Phenomenology of the Human Person is the interplay of a phenomenon's incidentals, properties, and essence as they emerge naturally in the prephilosophical human conversation. Although essences are not popular in modern or contemporary philosophy, Sokolowski shows how they need not be dismissed as occult entities, postulates of a philosophical reason; for, they show up phenomenologically if we allow philosophy to focus its attention on the human world, and not on discovering some hidden realm beneath or beyond the one with which we, as relational beings, are entwined. In normal human life, some speakers display themselves as deeply knowledgeable about a topic, distinguishing what is crucial or central to the phenomenon and responsible for other, more capricious features; likewise, other speakers betray themselves as seeing many features but as unable to distinguish the passing from the permanent, the superficial from the substantial, the caused from the causing in the phenomenon. This phenomenological difference between speakers - those who can and those who cannot make essential distinctions-is important in many human situations, and it proves the continued significance of the distinction between essences and incidentals. (One of the marks of Sokolowski's phenomenological style is to mine a discussion from the classical tradition, but then to adjust it and extend it using the resources of phenomenology. In this case, Sokolowski is adapting Aristotle's discussion of the predicables from Topics and of substance from Metaphysics, though he does so in a way, characteristic of him, that is informed by the scholastic tradition and by the need to reframe and correct the premodern presentation in light of modern developments and objections.)

\footnotetext{
${ }^{14}$ Sokolowski, "Husserl as Tutor in Philosophy", 308.

${ }^{15}$ Ibid., 309.
} 
Three further books-The God of Faith and Reason: Foundations of Christian Theology (1982), Eucharistic Presence: A Study in the Theology of Disclosure (1994), and Christian Faith and Human Understanding: Studies on the Eucharist, Trinity, and the Human Person (2006) - develop a "theology of disclosure" that is phenomenological, Sokolowski says, because it "bring[s] out the integrity of what [it] examines" and "examines the manifestation of things believed in Christian faith". ${ }^{16}$ Crucial to Sokolowski's philosophy of God is an emphasis on "the Christian distinction"- - a distinction between God and the world. The claim is that the divine is not part of the world, as paganism would have it, but is beyond the world and not dependent upon the world; God would no less be without the world, and with God there would be no less good if the world were not.

These works show his originality as a philosopher of God and a theologian, developing a phenomenological approach to Christian faith and the mysteries it confesses. His approach is at once faithful to the faith, consonant with theological tradition, and radical, since it shows phenomenology's ability to add something new to the tradition, bringing out presentational aspects of the articles of faith "without submerging what is believed into subjectivity". ${ }^{17}$ One aspect of the philosophical significance of these more theological works should be noted here. In putting his philosophical life publically at the service also of his faith, this philosopher not only displays his integrity as a man, but also defends the integrity of the person: for the complementarity of (and distinctions between) philosophical reason and faith puts questions to the single, whole human person who is both philosopher and believer, questions the person cannot avoid if he wishes honestly to be both and yet simultaneously one thinker.

Sokolowski's most influential work is probably also his simplest, Introduction to Phenomenology (2000). Widely read and translated, this short book is lucid, accurate, and deep as an entry into classical phenomenology. He serves up, simply and straightforwardly, the meat and potatoes of phenomenology, including the structure of perception, time, the self and intersubjectivity, parts and wholes, identities in manifolds, pictures, language, the imagination, and categorical objects. Simultaneously, in defending reason, our access to reality, and the integrity of the person as reasonable, the book also develops characteristically Sokolowskian themes. Gloriously lacking footnotes or endnotes, if anything, this book shows off its clarity, not its erudition (which is submerged for the sake of focus and brevity in what is a genuinely introductory text). Coming as it does from one of the world's preeminent phenomenologists, this simple book is conspicuously unostentatious.

While drawing on his reflections in other books and essays (especially Phenomenology of the Human Person), the remainder of this essay will focus on the theme of the concluding chapters of Introduction to Phenomenology. There, Sokolowski articulates phenomenology as philosophy and situates its significance within the full tradition of philosophy.

\footnotetext{
${ }^{16}$ Ibid., 305.

${ }^{17}$ Ibid., 305.
} 


\section{Philosophy's Emergence Out of the Human Conversation}

Taking a cue from Michael Oakeshott's essay "The Voice of Poetry in the Conversation of Mankind", in Phenomenology of the Human Person Sokolowski articulates philosophy as a reflection on the human conversation. This 'conversation' for Oakeshott seems to name what 'the lifeworld' names for phenomenologists. Oakeshott describes it as follows:

As civilized human beings, we are the inheritors, neither of an inquiry about ourselves and the world, nor of an accumulating body of information, but of a conversation, begun in the primeval forests and extended and made more articulate in the course of centuries. It is a conversation which goes on both in public and within each of ourselves .... Indeed, it seems not improbable that it was the engagement in this conversation (where talk is without a conclusion) that gave us our present appearance, man being descended from a race of apes who sat in talk so long and so late that they wore out their tails. Education, properly speaking, is an initiation into the skill and partnership of this conversation in which we learn to recognize the voices, to distinguish the proper occasions of utterance, and in which we acquire the intellectual and moral habits appropriate to conversation. And it is this conversation which, in the end, gives place and character to every human activity and utterance. ${ }^{18}$

Sokolowski seems to adopt this image from Oakeshott in order to emphasize two things: that prephilososophical and unscientific life is saturated and structured by logos and that philosophy emerges after this ordinary human conversation and presupposes it.

First, let us sketch Sokolowski's account of the origin of philosophy out of the human conversation. Not only do we participate in the human conversation; we also have a prereflective awareness of ourselves doing so. When we speak, we may signal our awareness of ourselves as participants and take responsibility for our contributions by using what Sokolowski calls the "declarative" use of the first person pronoun-as in "I think such and such", "I suppose", "I doubt such and such..." (The declarative is to be distinguished from the use of the first person pronouns in informatives, as in "I am more than five feet tall".) The declarative is an inconspicuous, initial expression of reflection on our own activities of apprehending the world as it appears to us and articulating it for others. The declarative does not only intimate our own responsibility for this apprehension and articulation-the signaling involved in speech already does so. Rather, by way of the declarative, the speaker announces ownership of his own activity as (what Sokolowski calls) datives and agents of truth, appropriating this activity before others.

In a further move beyond the declarative, we engage also in propositional reflection. Propositional reflection occurs when we consider a claim not naively, not in passive assumption, but in quotation marks, as proffered by a speaker who is responsible for the claim. A neighbor may tell me, for example, that he attended Harvard. In normal conversation, without any clues hinting otherwise, I would take this as simply true. It may happen, however, that clues do present themselves: I wonder

\footnotetext{
${ }^{18}$ Oakeshott, Michael. 1991. "The Voice of Poetry in the Conversation of Mankind". In Rationalism in Politics and Other Essays. Indianapolis: Liberty Fund, 490.
} 
how he could have done so given that he does not seem terribly intelligent, or perhaps I have begun to suspect him of habitually telling self-flattering tall tales. If clues motivating doubt are there, I suspend judgment in the truth of the claim. The claim is left there hanging, as something to be verified or confirmed but not simply accepted. The claim has been made into a proposition, something merely proposed. It is not a fact, but a fact as supposed.

It is not the case that the proposition is an entity that exists prior to our move into the propositional attitude, as though the sentence were the proposition with assent added to it. In considering a proposition, "we do not subtract or withhold assent, we annul it. Turning a fact into a proposition is a positive achievement, a modification, not the removal of an element". ${ }^{19}$ Sokolowski emphasizes that, in this way, phenomenology can account for the origin and being of propositions arising from normal human conversation: there is no need for a separated realm of logical entities. "This [would be] the typical philosophical mistake of making an independent thing out of something that is a moment dependent on something else", he explains. ${ }^{20}$ In fact, the proposition is dependent upon our turn toward it; it arises in our shift into the propositional attitude.

Once we have, through normal childhood learning, acquired the ability to propositionalize claims, we may develop the ability to do so at will, without the need for motivating clues. Some people are more dexterous with propositional reflection than others, and human beings can habitualize this attitude in what is often called 'critical thinking.' Sokolowski remarks on the human significance of this ability and its failures:

There are two extremes in the attitude people have to what is said. Some listeners are gullible and go along with every report and registration they hear. For them, speech is compelling... At the other extreme there are persons who have become so critical or so suspicious that they hardly ever go along with a report or registration. They trip up almost any remark, even those that are meant to be casual and uncontroversial, the harmless statements that keep human contact and sympathy alive. ${ }^{21}$

Though skill at propositional reflection is a virtue, and an important human achievement, this habit can also be distorted, undermining the person's ability to engage in conversation in a friendly way. Not only does this hypertrophied critical attitude undermine lifewordly goods, it also is mistaken by some as philosophy. "Someone who can't get out of the natural attitude can't seem to help mistaking philosophy for denial or doubt. But philosophy sustains ordinary experience in a special, detached way. In fact, it's the only defense the ordinary has against sophistic assault". ${ }^{22}$

Propositional reflection enhances the declarative. Both remain within the natural, human conversation while giving the persons involved in them some distance from the predicational moves made in our common life. But the propositional goes further. Compared to the conversational declarative, the propositional turn takes more

\footnotetext{
${ }^{19}$ Sokolowski, Presence and Absence, 59.

${ }^{20}$ Ibid., 111.

${ }^{21}$ Ibid., 111.

${ }^{22}$ Sokolowski, Husserlian Meditations, 192.
} 
effort and is a more explicit break from default, natural acceptance of claims made in the human conversation.

Sokolowski emphasizes that although propositional reflection is often confused for philosophical reflection, they are not the same. One difference between them is scope. Propositional reflection is performed piecemeal on particular claims, which we put in quotation marks until we decide upon them. There is also a difference in attitude. While it is true that propositional reflection breaks with natural acceptance of a claim, because this is done piecemeal, these parts, though momentarily up in the air, maintain their trajectory toward verification or falsification.

\begin{abstract}
At the beginning, we go along with whatever we hear being said. Even when we begin to distinguish between fact and proposal, the syntactical articulation that we must continue to perform while we entertain something as supposed pulls along with itself a tendency to assent. The rhetorical force of the syntax continues to work on us, and we must remain cool in resisting it. Besides intellectual expertness in distinguishing fact and fact as supposed, a certain emotional control is required to tolerate a proposition as only a supposition. ${ }^{23}$
\end{abstract}

The claims maintain their status as within the human conversation, and they carry a certain emotional impetus in us. Thus, Sokolowski tells us, "there is something pragmatic about propositional reflection": the proposition is there to be decided upon, to be disconfirmed and thus crossed out, or to be confirmed and thus have its quotation marks removed. ${ }^{24}$

Rather than piecemeal, philosophical reflection is universal in scope, and rather than pragmatic, philosophical reflection is contemplative. Without distinguishing these two forms of reflection, we will "confuse philosophical analysis with conceptual clarification". ${ }^{25}$

Suspending the whole instead of one or two pieces within it changes our reflection's character from pragmatic to contemplative. To do so means that one has stepped outside the natural attitude of belief tout court; one has bracketed the world and suspended our world-belief. Phenomenologists will recognize that this is Sokolowski's account of Husserl's epochē.

Thus, Sokolowski explains the origin of philosophy out of the human conversation by way of the mediating steps of the declarative and its enhancement in the propositional attitude. With the declarative use of the first person pronoun and propositional reflection, human beings move closer to philosophy. As we move more and more to the margins of the human conversation, our reflection becomes more global rather than partial, and we gain a cool distance from the heat and pressure of the situations dominating our common life. We loosen ourselves from the partial and pragmatic concerns of the natural attitude, but our activity of philosophy remains "parasitic on what is achieved before it begins its explorations". ${ }^{26}$

\footnotetext{
${ }^{23}$ Sokolowski, Presence and Absence, 60.

${ }^{24}$ Sokolowski, Robert. 2000. Introduction to Phenomenology. New York: Cambridge University Press, 190.

${ }^{25}$ Sokolowski, "Husserl as Tutor in Philosophy", 302.

${ }^{26}$ Sokolowski, Presence and Absence, 5.
} 


\section{Philosophy's Relation to the Human Conversation}

Next, let us remark on Sokolowski's understanding of the target of philosophy's reflections. To identify the human conversation, rather than things, as the object of philosophical reflection might seem, from a phenomenological point of view (well rehearsed, as it is, in the idealism-realism debate), to suggest that Sokolowski is accepting that we must stay within human consciousness. But this is not right. The human conversation is public. It is our shared life structured by reason, by our syntaxes and categorialities. By articulating philosophy's target as our shared conversation—which is essentially public and interpersonal—and not merely the activities of consciousness, Sokolowski gently corrects what has turned out to be a problematic Husserlian manner of speaking, which can suggest a path toward an isolated ego.

While sometimes the epoche is thought of as a version of methodological solipsism, Sokolowski's choice of words helps us avoid the mistaken solipsistic interpretation. For Sokolowski, Husserl's discovery of intentionality and his development of the transcendental reduction expose not a solitary ego, but the relational character of the person. Human thought has two types of relationalities that speak against the solipsistic interpretation of philosophy. First, human thought is characterized by a relationality to objects: "Thinking is not something that we do entirely on our own; we are allowed to think by what our thoughts are about". ${ }^{27}$ This happens, namely, because of intentionality; with Husserl's doctrine, "suddenly everything is restored, taken out of the grip of that Cartesian, Lockean obsession with immanence and privacy. Everything is there to be philosophically repossessed". ${ }^{28}$ Second, human thought is characterized by a relationality to the human conversation itself and those other persons who have incorporated us into their conversations (intersubjectivity): "As human persons, we owe our rational life to those who have shared with us their thoughts, the way the world appeared to them". ${ }^{29}$

To identify the human conversation as the object of philosophical reflection might seem, from a classical point of view, to suggest that we have decided to adopt the modern turn to the subject at the cost of the ancient concern for being, its sources, and its highest causes. But Sokolowski is careful to avoid this mistake, also. $\mathrm{He}$ describes the object of philosophical reflection as "the human conversation in its amplitude, with the inclusion of the things that are brought into the conversation and correlated with it". ${ }^{30}$ That is, in philosophy we focus for reflection on our own activities as datives and agents of truth, but as datives and agents of truth we are involved with all things that appear to us, so that in philosophy we reflect also on everything that surfaces as topics of human conversation. Whereas Aristotle, in passing in the

\footnotetext{
${ }^{27}$ Sokolowski, Presence and Absence, xv.

${ }^{28}$ Sokolowski, "Husserl as Tutor in Philosophy", 297.

${ }^{29}$ Sokolowski, Robert. 2008. Phenomenology of the Human Person. New York: Cambridge University Press, 79.

${ }^{30}$ Ibid., 3 .
} 
Politics, says it is the job of philosophy "to speak the truth about each thing", Sokolowski seems to suggest here a friendly amendment: the job of philosophy is to speak the truth about the speaking of truth about each thing. This only sounds deflationary; Sokolowski maintains philosophy's ancient comprehensive obligations to the whole of being, and not just our subjective activities, since these two are phenomenologically correlated. "Philosophy strives to speak from a final context, a context beyond which there is no other... This comprehensive view includes not only the whole of things but also the activity of knowing things and speaking about them". ${ }^{31}$ Philosophy "reflects on all things, insofar as they become phenomena and legomena". 32

Thus, in Sokolowski's understanding of the epoche, of the move into the philosophical attitude, we can take seriously the modern concern for the subject while avoiding solipsism and the ancient concern for being without forgetting about the activities of the subject. "The resources provided by phenomenology allow us, I believe, to transcend the difference between ancients and moderns. They offer a way to pursue philosophy as such, without being forced to be contemporary only at the price of turning away from the ancients". ${ }^{33}$

Finally, Sokolowski remarks that, though it often goes unnoticed, philosophy is not on all fours with other modes of voice in this conversation, because it is interested primarily not in this or that thing or event, but in the dimension of the conversation itself. Sokolowski tells us,

The human conversation is a whole; it is the human, subjective correlate of the whole of things. Philosophy reflects on the conversation and its objective correlates. Is philosophy itself not just one voice within the human conversation? It reflects on the whole, but does not this reflection put it somehow outside the whole? Or does it become just one part within the whole? This conundrum cannot be avoided. It is the perpetual burden (or amusement) of philosophers, and it explains why philosophy will inevitably be misunderstood as being psychology, ideology, rhetoric, poetry, or science. It must simply be recognized and maintained as a special issue within human understanding. It cannot be resolved by somehow detaching philosophy from the whole of things, or by reducing it to a partial science that would refuse to consider the whole. The human theoretic life comes to its completion in this perplexity, which really does not remain disturbing once it is recognized as inevitable.... It is simply one more thing to be formulated as best we can. ${ }^{34}$

The ambiguous position of philosophy, as both inside and outside the human conversation, necessarily causes confusions and public relations problems. When trying to articulate something essential about human discourse and the world, philosophers will often be heard as just another one of the voices in the conversation next to other modes of discourse-practical, artistic, scientific, and disciplinary voices. Thus, Sokolowski says, philosophy is "balanced on the edge" 35 of natural human discourse, and its contributions to the conversation are usually misunderstood.

\footnotetext{
${ }^{31}$ Ibid., 312.

${ }^{32}$ Ibid., 220.

${ }^{33}$ Ibid., 273.

${ }^{34}$ Ibid., 221.

${ }^{35}$ Ibid., 304.
} 
Philosophers require what Sokolowski calls a "rhetorical prudence" in presenting themselves. ${ }^{36}$

Sokolowski often emphasizes the difference between philosophical and prephilosophical discourse, calling the idiom of the first "transcendentalese" and that of the second "mundanese" (following Thomas Prufer). In engaging with each other philosophically, we must use the natural language given us, but this is difficult because the objects it names are standard things of the lifeworld; our words are not made for discussing the dimension of the presencing and absenting of things, which is philosophy's focus. Thus, philosophy must "trope" its words in new ways, adopting analogical uses of mundane terms to describe this transcendental dimension (Sokolowski is here by analogy adopting and adapting the classical response to the "problem of divine names"). Many philosophical errors occur because of a failure to mind the gap between these two attitudes and modes of discourse. Without keeping track of our discourse as in transcendentalese, "we cannot recognize philosophical discourse for what it is. We would keep confusing it for ordinary talk". ${ }^{37}$

The way that philosophy has been defined here, as distinct from propositional reflection and as having a responsibility to reflect on the whole of being in "its human involvement", portrays philosophy as a paradoxical enterprise. Let me put this in a pointed way. It seems to me that philosophy inherently has two features that pull us in opposite directions: first, the attempt at knowing the whole, omniscience; and, second, the need to remember the subject, the requirement for the philosophizing person to know himself as mortal with only human wisdom. This is the paradox that Sokolowksi (quoted above) says is ultimate and inevitable for philosophy as at once both inside and outside the human conversation. About the paradoxical human attempt to know the whole, Sokolowski explains:

The philosopher is omniscient only formally and only in principle, that is, only potentially. People sometimes complain that a philosopher pretends to be a know-it-all, and that he tries to tell everybody else what they are doing. But the complaint is unjustified. It is true, that if someone presents himself as a philosopher, he will not be able to recuse himself from any philosophical question. He is called, in his profession, to address the whole of things and to show how the parts differentiate themselves within the whole.... The potential omniscience of the philosopher is chastening, because, like Socrates, he is always aware that he does not know but is obliged to know. ${ }^{38}$

This tension between the human and super-human is essential to philosophizing. For example, when Lady Philosophy appears in Boethius's prison cell, her eyes have "a more than human keenness", and though she seems sometimes of averagely human height, at other times, when she stands up she seems to "pierce the very heavens and baffle the eyes that look upon her". ${ }^{39}$ In a similar way, Husserl distinguishes between "philosophy as a historical fact at a given time and philosophy as

\footnotetext{
${ }^{36}$ Ibid., 221.

${ }^{37}$ Sokolowski, Husserlian Meditations, 122.

${ }^{38}$ Sokolowski, Phenomenology of the Human Person, 321.

${ }^{39}$ Boethius, Ancius. 1897. The Consolation of Philosophy of Boethius. Trans. H. R. James. London: Elliot Stock, 6.
} 
idea, as infinite task". ${ }^{40}$ This task is a calling we cannot abandon (if we still aim to be philosophers), yet one we must recognize as beyond us. This "problematic telos of philosophy", as Husserl calls it, makes it an "enigma" for those engaged in it. ${ }^{41}$ We must remain always unsatisfied and perhaps a little guilty feeling.

Sokolowski's friend and philosophical influence, Thomas Prufer captures the same paradox and explains the existential situation it creates for those who attempt this type of reflection on the whole:

Philosophy, perhaps more than any other human endeavor, is shadowed by the temptation to give itself up, and this is because the gap between its intention and achievement is so great. The infinite and accurate statement of being is never actual; hence the temptation to unarm the philosophical eros.... The philosophical life is the erotic life par excellence, and eros neither achieves plenty nor is it satisfied in poverty. From the point of view of ordinary life and of the arts and sciences, a point of view from which more can be achieved because less is intended, philosophy often seems presumptuous nonsense. And philosophy's preoccupation with reflection on its own act usually leads to oscillation between confessing its failures and renewing its pretensions. ${ }^{42}$

It seems to me that the today's danger, the way in which philosophy is now tempted to "give itself up", to escape from this oscillation between (in David Hume's words) "philosophical melancholy and delirium", is by making itself simply another one of the voices in the human conversation, making itself another one of the disciplines, another branch of partial knowledge, and then to disperse itself further into subfields. By becoming piecemeal again, philosophical reflection would also give up its distance from the particular beings reflected upon; it would corrupt its contemplative character and take on the pragmatic tone of confirming and disconfirming mundane claims that appear within the human conversation, within the natural attitude.

\section{Philosophy's Recovery from Modernity}

Sokolowski understands modernity as, in part, a change in philosophy's attitude toward its own task. It is clear that the early modern philosophers, such as Machiavelli, Hobbes, Bacon, and Descartes, understood themselves as making a radical break with philosophy as it had been done. They historicized philosophy by marking themselves as moderns and rejecting the relevance of previous "ancient" philosophy or (in Descartes" phrase) philosophy as it was done "in the schools". As Francis Slade - a friend of Sokolowski's who influenced him especially on this topic_-puts it, "All philosophy insofar as it is philosophy is contemporary", but the historicization essential to modern philosophy "is intended to divest philosophy as

\footnotetext{
${ }^{40}$ Husserl, Edmund. 1970. The Crisis of European Sciences and Transcendental Phenomenology. Translated by David Carr. Evanston, Ill.: Northwestern University Press, 291.

${ }^{41}$ Husserl, Crisis, 394.

${ }^{42}$ Prufer, Thomas. 1965. "Dasein and the Ontological Status of the Speaker of Philosophical Discourse". 20th-Century Thinkers: Studies in the Work of Seventeen Modern Philosophers. Ed. J. K. Ryan. Staten Island, N.Y.: Alba House, 165.
} 
it has been practiced of philosophical significance except as something that has to be overcome and replaced". It is "a rhetorical posture, a tactic for winning an argument". ${ }^{43}$ The moderns announced themselves as the new beginning, accomplishing a rupture with previous, obsolete philosophy.

What is the nature of this break? It begins in a new attitude toward the human conversation, toward what appears to human beings, toward the verifications and accomplishments of prephilosophical human life.

As Sokolowski explains, in both halves of modern philosophy, epistemological and political, "mind is to be understood as the power to rule". ${ }^{44}$ The moderns erect an impersonal philosophical reason (epistemological method or rational sovereignty ending the state of nature) over against the human conversation, against what appears to human beings, the verifications and accomplishments of mundane life. Rather than admiring and clarifying the necessities in human veracity, moderns seek to replace the natural attitude, to rule it, thus becoming pragmatic-as Descartes announces that he is putting a practical philosophy in place of the speculative one he inherited. For the moderns, "the mind is not conceived as ordered toward the truth of things, but as governing its own activities and generating the truth through its own efforts. The mind is not receptive, but creative". ${ }^{45}$ In contrast, for Sokolowski, "The mind is both receptive and active". ${ }^{46}$ For phenomenology, "the human mind finds its end in the evidence of things". ${ }^{47}$ Though he admits that some aspects of Husserl's philosophy seem to mark Husserl as modern, phenomenology learns from the modern turn without remaining simply modern. "While phenomenology originates in modernity, it also takes a distance from it". ${ }^{48}$

Phenomenologists usually focus on the epistemological half of the modern break, but Sokolowski emphasizes that modern political philosophy is involved, too, and that these two halves are related. Modern political philosophy does not look at the human community and its modes of rule-in which some person or group is always ruling another, or providing an account about why they should-as the focus of its contemplative understanding. Rather, modern political philosophy invents a new formal conceptualization of our situation in order to change the nature of the human political community. Sovereignty-the sovereign as impersonal, rational, tautologically justified rule-is modernity's self-constructed political form. Sokolowski writes,

In the modern state, a new entity is created, the sovereign. The sovereign is not one group of people in the body politic. The sovereign is a construct, not a spontaneous human development or a natural form of human association. It is an invention of philosophers. It is

\footnotetext{
${ }^{43}$ Slade, Francis. "Two Versions of Political Philosophy: Teleology and the Conceptual Genesis of the Modern State". In Natural Moral Law in Contemporary Society, ed. H. Zaborowski. Washington D.C.: The Catholic University of America Press, 238.

${ }^{44}$ Sokolowski, Introduction to Phenomenology, 202.

${ }^{45}$ Ibid., 201.

${ }^{46}$ Sokolowski, Presence and Absence, 156.

${ }^{47}$ Sokolowski, Introduction to Phenomenology, 203.

${ }^{48}$ Ibid., 198.
} 
proposed as a permanent solution to the human political problem. The introduction of the sovereign is to put an end to the interminable human struggle, carried on by individuals and by groups, to rule. The concept of sovereignty is meant to rationalize human political life. It puts in place a structure that is impersonal, in contrast with the personalized forms of rule found in the ancient and medieval city. ${ }^{49}$

The state of nature for human beings is not prepolitical. It is Aristotle's city, where we give reasons about who should be in charge and what the common good is. This is the state of nature that the Leviathan attempts to sweep away. The rational modern state would like to put an end to the natural, messy play of opinions. It does so with the philosophical idea of sovereignty, which is the political equivalent of Descartes' method for discovering the truth. And the state of nature for human beings is not prelinguistic, either. It is Oakeshott's "conversation of mankind" in which we enjoy chatting and arguing, and in which we, by sharing our minds, help each other develop mindfulness and allow each other to see the world better. This is the state of nature that modern method attempts to replace, for modern epistemology reconstructs truth on its own terms rather than honoring the fact that even prephilosophical human beings essentially and successfully share in logos, as datives and agents of truth.

In this context of his understanding of modern philosophy, we see the importance of Sokolowski's consistent claim, in all his major works, that philosophy remains always dependent and reflective on prephilosophical human life, that the world as it shows us prephilosophically is worthy of our engagement and its goods worthy of protection, and that the prephilosophical human person-despite the absences, vaguenesses, and mistakes coincident with human veracity - has integrity as a rational agent, contemplatively and practically.

Of course, Sokolowski does not present phenomenology as merely rejecting modernity. Rather, the important point is that phenomenology allows a recovery that is not a mere restoration. Husserl's breakthrough

opened up a context within which all the philosophical capital of antiquity and the middle ages, as well as that of modernity, can be retrieved. If we grasp the issue of presence, absence, difference and identity correctly, we need not abandon what went before but can possess it all in a new light. We need not merely repeat the past but we do not have to run away from it either. Addressing the issue of presence and absence is an appropriate modern way of raising the question of being. ${ }^{50}$

\section{Conclusion}

Aurel Kolnai remarks, "the future historiography of ideas ... will set it down as a common place that with Husserl commences the non-Cartesian Age in European thought" ${ }^{51}$ Phenomenology is a twentieth century movement within the history of

\footnotetext{
${ }^{49}$ Ibid., 199.

${ }^{50}$ Sokolowski, "Husserl as Tutor in Philosophy", 300-1.

${ }^{51}$ Kolnai, Aurel. 1999. Political Memoirs. Ed. F. Murphy. New York: Lexington Books, 127.
} 
philosophy. Its founder, Edmund Husserl, learned how to philosophize influenced primarily by late nineteenth century movements in philosophy, mathematics, psychology, and the sciences. Though he read other texts from the history of philosophy, his knowledge here was unsystematic, often perceptive but lacking scholarly care. References to these texts are not often found in his published writings. They are found in his lectures and appear most seriously in his final work, The Crisis of European Sciences and Transcendental Phenomenology, and its associated texts, where, as in his lectures, the texts and thinkers referenced are primarily canonical pieces of modern philosophy. What comes across clearly when Husserl discusses texts and thinkers from thought's past is that he views his phenomenology as an epoch-making breakthrough, one that both fulfills and moves beyond modern philosophy and the Enlightenment.

Despite the fact that Husserl was convinced about himself that he had moved beyond philosophical modernity, critics and historiographers often place him less flatteringly as the last German idealist, as Heidegger's preface, or as thoroughly an academic of his time devoted to the rationalistic project of fin de siècle science. His texts provide enough data for people who wish to dismiss him in these ways, and none of these accounts completely lack elements of truth. Each of us arrives at a time and place, in particular communities, and we are inducted into intellectual life through contemporary conversations. We are formed by our predecessors and judged by our successors. When we act or speak, we must act or speak on stages we have not set ourselves, responding to what happened just before our arrival and to what just happens now to be going on around us. That does not mean that when we act or speak we are swallowed up in these surroundings. Though all men are men of their time, a successful man is never merely that.

Husserl was not as prepared as one might wish to articulate what about his thought marked it off from his modern predecessors'. One of Robert Sokolowski's great contributions is that he has done so, and he has been able to do so because he has a keener understanding of the history of philosophy_of philosophy's beginning with the ancient Greeks, of the medieval appropriation of philosophy that sought to make room for natural reason within the context of revelation, and of modern philosophy's attempt at a new start, rejecting its predecessors as mere history and thus as philosophically irrelevant. Sokolowski situates phenomenology within this past of thought, and by doing so allows us to appreciate Husserl's marvelous achievement against this backdrop. This might make it sound as though Husserl's achievement was merely one against a backdrop, epoch-making and revolutionary, as though it were utterly new-yet another modern attempt at another modernity. With the help of Sokolowski's reflections, we understand phenomenology both as new and as recovery, as epoch-making and as development, and as a development not only within the modern philosophy but of philosophy simply speaking. With Sokolowski's Husserl, we find one path to recover philosophy.

It is easy to lose the forest of philosophy amid Husserl's trees, to be exhausted just reading about his indefatigable work ethic for phenomenology's infinite tasks, to grow forgetful of phenomenological philosophy within phenomenological analyses. Sokolowski helps readers understand how phenomenology is truly a form of 
philosophy in continuity with, while making a novel contribution to, a perennial tradition. He does so while articulating — and, better, showing by example-what philosophy does, transcending its ancient, medieval, or modern forms, and its contemporary diaspora into subfields.

\section{References}

Boethius, Ancius. 1897. The Consolation of Philosophy of Boethius. (Trans: James, H.R.). London: Elliot Stock.

Drummond, John J., and James G. Hart, eds. 1996. The Truthful and the Good. Essays in Honor of Robert Sokolowski. Boston: Kluwer Academic Publishers.

Husserl, Edmund. 1970. The Crisis of European Sciences and Transcendental Phenomenology. (Trans: by David Carr.). Evanston: Northwestern University Press.

Kolnai, Aurel. 1999. In Political Memoirs, ed. F. Murphy. New York: Lexington Books.

Mansini Guy, O.S.B., and James G. Hart. 2003. Ethics and Theological Disclosures: The Thought of Robert Sokolowski. Washington, DC: The Catholic University of America Press.

Oakeshott, Michael. 1991. The Voice of Poetry in the Conversation of Mankind. In Rationalism in Politics and Other Essays, 488-541. Indianapolis: Liberty Fund.

Prufer, Thomas. 1965. Dasein and the Ontological Status of the Speaker of Philosophical Discourse. In Twentieth-Century Thinkers: Studies in the Work of Seventeen Modern Philosophers, ed. J. K. Ryan, 159-73. Staten Island: Alba House.

Slade, Francis. 2010. Two Versions of Political Philosophy: Teleology and the Conceptual Genesis of the Modern State. In Natural Moral Law in Contemporary Society, ed. H. Zaborowski, 235263. Washington, DC: The Catholic University of America Press.

Sokolowski, Robert. 1964. The Formation of Husserl's Concept of Constitution, Phaenomenologica 18. Den Haag: Martinus Nijhoff.

— 1974. Husserlian Meditations: How Words Present Things. Evanston: Northwestern University Press.

- 1978. Presence and Absence: A Philosophical Investigation of Language and Being. Bloomington: Indiana University Press.

. 1982. The God of Faith and Reason: Foundations of Christian Theology. Notre Dame: University of Notre Dame Press.

- 1985. Moral Action: A Phenomenological Study. Bloomington: Indiana University Press.

- 1988. Husserl as Tutor in Philosophy. Journal of the British Society for Phenomenology 19 (3): 296-310.

. 1992. Pictures, Quotations, and Distinctions: Fourteen Essays in Phenomenology. Notre Dame: University of Notre Dame Press.

. 1994. Eucharistic Presence: A Study in The Theology of Disclosure. Washington, DC: The Catholic University of America Press.

- 2000. Introduction to Phenomenology. New York: Cambridge University Press.

- 2006. Christian Faith and Human Understanding: Studies on the Eucharist, Trinity, and the Human Person. Washington, DC: The Catholic University of America Press.

- 2008. Phenomenology of the Human Person. New York: Cambridge University Press.

Molly Brigid McGrath (1977) is Associate Professor of Philosophy at Assumption College in Worcester, Massachusetts, U.S.A. Her areas of research are: Husserlian phenomenology, social and political philosophy, the history of philosophy, philosophy and film. 